\title{
Escape from p53-mediated tumor surveillance in neuroblastoma: switching off the p14 ${ }^{\mathrm{ARF}}$-MDM2-p53 axis
}

\author{
T Van Maerken ${ }^{\star, 1,2}$, J Vandesompele ${ }^{1}$, A Rihani ${ }^{1}$, A De Paepe ${ }^{1}$ and F Speleman ${ }^{1}$
}

A primary failsafe program against unrestrained proliferation and oncogenesis is provided by the p53 tumor suppressor protein, inactivation of which is considered as a hallmark of cancer. Intriguingly, mutations of the TP53 gene are rarely encountered in neuroblastoma tumors, suggesting that alternative p53-inactivating lesions account for escape from p53 control in this childhood malignancy. Several recent studies have shed light on the mechanisms by which neuroblastoma cells circumvent the p53-driven antitumor barrier. We review here these mechanisms for evasion of p53-mediated growth control and conclude that deregulation of the p14 ${ }^{\mathrm{ARF}}-\mathrm{MDM} 2-\mathrm{p} 53$ axis seems to be the principal mode of p53 inactivation in neuroblastoma, opening new perspectives for targeted therapeutic intervention.

Cell Death and Differentiation (2009) 16, 1563-1572; doi:10.1038/cdd.2009.138; published online 25 September 2009

The p53 tumor surveillance network constitutes the core defense mechanism of the cell against loss of genomic integrity and malignant transformation. Evasion of p53 activity is, therefore, a prerequisite for tumor cells to survive and thrive, and this is attainable either through mutation of the TP53 gene or through defects in the molecular components that govern or execute the various aspects of the p53 response. Elucidation of the mechanisms by which tumor cells override the p53-orchestrated failsafe program is not only important to gain insight into the ontogenesis of a tumor, but may also point to preferable modes of therapeutic intervention.

A striking feature of the childhood cancer neuroblastoma is the low frequency $(<2 \%)$ of TP53 mutations at diagnosis. ${ }^{1}$ There is considerable evidence that TP53 mutations may be acquired during chemotherapy and malignant progression of neuroblastoma. ${ }^{1-4}$ Accordingly, an increased frequency of TP53 mutations is observed in multidrug-resistant neuroblastoma cell lines and in neuroblastoma cell lines established at relapse, but even in this context, the majority of cell lines remain characterized by a wild-type TP53 gene. ${ }^{5,6}$ Furthermore, many studies indicate that the p53 signal transduction pathway is intrinsically intact in neuroblastoma, ${ }^{1,4,7-9}$ suggesting that circumvention of the p53 barrier in this tumor entity relies primarily on an inappropriately increased activity of inhibitors of p53 signaling or, alternatively, on a loss of positive regulators of $\mathrm{p} 53$ activity. This review summarizes our current understanding of the mechanisms by which neuroblastoma cells escape from p53-mediated tumor surveillance and positions deregulation of the p14 ${ }^{\mathrm{ARF}}$-MDM2-p53 axis as a central switch for p53 inactivation in neuroblastoma.

The p14 ${ }^{\mathrm{ARF}}$-MDM2-p53 Axis and Lesions at the MDM2 and CDKN2A $\left(p 16^{I N K 4 a} / p 14^{A R F}\right)$ Loci in Neuroblastoma

The MDM2 oncoprotein, a human homolog of the 'mouse double minute 2' gene product that was originally identified in a spontaneously transformed mouse cell line with double minute chromosomes, ${ }^{10}$ is a critical negative regulator of p53 stability and activity. It has been well established that p53 and MDM2 mutually control their cellular levels and form a tight autoregulatory feedback loop (Figure 1a). Under normal physiological conditions, p53 protein levels are very low because of MDM2-dependent proteasomal degradation. ${ }^{11}$ Exposure of cells to harmful stimuli, such as DNA damage, hypoxia, telomere erosion, ribonucleotide depletion, or oncogene activation, results in a number of modifications on the p53 protein (e.g. phosphorylation and acetylation), which suppress the binding of p53 to MDM2 and which lead to accumulation and increased transcriptional activity of p53. ${ }^{12}$ In addition to inducing expression of target genes involved in cell-cycle arrest, DNA damage repair, senescence, and apoptosis, p53 also transactivates the MDM2 gene (Figure 1b). The resulting increase in MDM2 expression limits

\footnotetext{
${ }^{1}$ Center for Medical Genetics, Ghent University Hospital, Ghent, Belgium and ${ }^{2}$ Department of Clinical Chemistry, Microbiology and Immunology, Ghent University Hospital, Ghent, Belgium

*Corresponding author: T Van Maerken, Center for Medical Genetics, Ghent University Hospital, De Pintelaan 185, Ghent B-9000, Belgium.

Tel: + 329332 0352; Fax: + 329332 6549; E-mail: Tom.VanMaerken@UGent.be

Keywords: neuroblastoma; p53; antitumor barrier; MDM2; p14 ${ }^{\mathrm{ARF}}$

Abbreviations: bHLH, basic helix-loop-helix; CHD5, chromodomain helicase DNA-binding protein 5; ChIP, chromatin immunoprecipitation; chromo, chromatinorganizing modulator; MDM2, mouse double minute 2 homolog; MEFs, mouse embryonic fibroblasts; $p 14^{A R F}$, human alternate reading frame protein of $14 \mathrm{kDa}$; $p 19^{\mathrm{ARF}}$, murine alternate reading frame protein of $19 \mathrm{kDa}$; Parc, p53-associated parkin-like cytoplasmic protein; pRb, retinoblastoma protein; SNP309, single nucleotide polymorphism at position 309 ( $\mathrm{T}>\mathrm{G})$ in MDM2; Wip1, wild-type p53-induced phosphatase 1

Received 06.7.09; accepted 27.7.09; Edited by V De Laurenzi; published online 25.9.09
} 
a

b

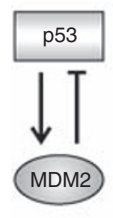

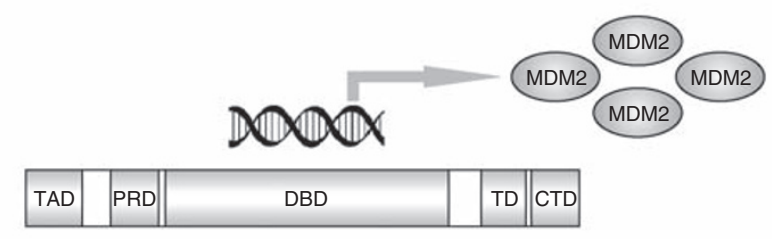

c

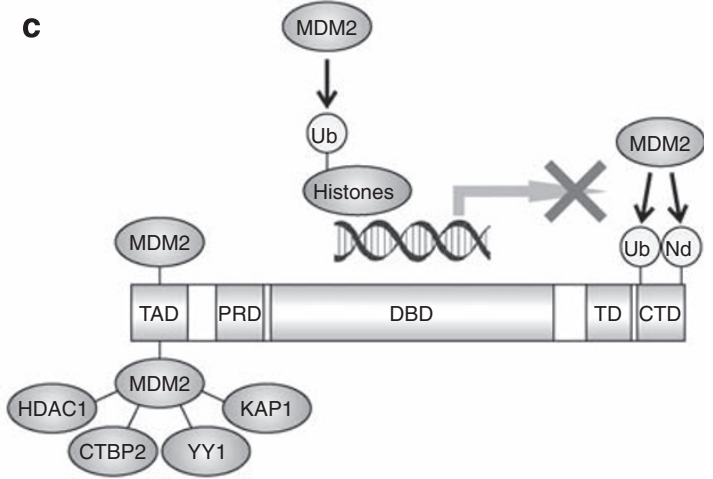

Figure 1 The p53-MDM2 autoregulatory feedback loop. (a) The p53 protein induces expression of MDM2, which negatively regulates the stability and activity of p53, providing a means to keep p53 levels and activity low in unstressed cells and to switch off p53 at the end of a stress response. (b) The p53-mediated expression of MDM2 results from binding of p53 to response elements in the MDM2 gene and subsequent transactivation of MDM2. The domain structure of p53 is shown schematically: TAD, transactivation domain, amino acids 1-40; PRD, proline-rich domain, amino acids 61-94; DBD, DNA-binding domain, amino acids 100-300; TD, tetramerization domain, amino acids 324-355; CTD, C-terminal regulatory domain, amino acids 360-393. (c) The p53-inhibitory activity of MDM2 relies on multiple mechanisms. Binding of MDM2 to p53 conceals the TAD and consequently blocks the transcriptional activity of p53. MDM2 also recruits several corepressor proteins to p53, including HDAC1, CTBP2, YY1, and KAP1. The E3 ubiquitin ligase activity of MDM2 results in ubiquitination of lysine residues in the CTD of p53, preventing acetylation of p53, favoring nuclear export, and promoting proteasomal degradation (see text for details). Some of these lysine residues can also be neddylated by MDM2, resulting in inhibition of the transcriptional activity of p53. Finally, MDM2 may also serve as a p53-specific transcriptional silencer by binding and monoubiquitinating histone proteins in the proximity of p53-responsive promoters. $\mathrm{Nd}$, NEDD8; Ub, ubiquitin. The color reproduction of this figure is available on the html full text version of the manuscript

the duration and intensity of a non-lethal stress response. There are several mechanisms by which MDM2 is capable of counteracting p53 activity and stability (Figure 1c). First, MDM2 binds to the transactivation domain of p53 and, therefore, directly interferes with recruitment of the basal transcriptional machinery and transcriptional coactivators. ${ }^{13-15}$ Second, MDM2 acts as an E3 ubiquitin ligase for p53 in a dosage-dependent manner. Low levels of MDM2 promote $\mathrm{p} 53$ monoubiquitination, which may both stimulate nucleocytoplasmic shuttling of p53 because of unmasking of a nuclear export signal and decrease p53 transactivation capacity owing to unavailability of the ubiquitinated lysine residues for acetylation. At higher levels, the activity of MDM2 results in polyubiquitination and subsequent proteasomal degradation of p53. ${ }^{11,16,17}$ Third, MDM2 also induces monoubiquitination of histone proteins in the vicinity of p53-responsive promoters, resulting in transcriptional repression. ${ }^{18}$ Fourth, MDM2 has been reported to inhibit p53 transcriptional activity by promoting conjugation of the ubiquitin-like protein NEDD8 to p53. ${ }^{19}$ Fifth, MDM2 may also contribute to p53 inactivation by recruiting several corepressor proteins, such as HDAC1, ${ }^{20}$ CTBP2 ${ }^{21}{ }^{\mathrm{YY}} 1,{ }^{22}$ and KAP1. ${ }^{23}$

A central negative regulator of MDM2 is the tumor suppressor protein $\mathrm{p} 14^{\mathrm{ARF}}$, which is an alternate reading frame product of the CDKN2A locus on chromosome 9p21. This locus encodes two structurally unrelated growth-inhibitory proteins, $\mathrm{p} 16^{\mathrm{INK} 4 \mathrm{a}}$ and $\mathrm{p} 14^{\mathrm{ARF}}$, that govern the activities of the pRb and p53 tumor suppressor pathways, respectively. ${ }^{24}$ The $\mathrm{p} 14^{\mathrm{ARF}}$ protein serves as a key sensor of hyperproliferative signals generated by activated oncogenes and engages both p53-dependent and p53-independent pathways to protect cells from malignant transformation. ${ }^{25}$ The importance of $\mathrm{p} 14^{\mathrm{ARF}}$-mediated signaling of oncogene activity in the $p 53$ tumor surveillance network is underscored by observations in mice models that the cancer-protective activity of p53 is abolished in the absence of the murine homolog $\mathrm{p} 19^{\mathrm{ARF}}{ }^{26,27}$ The physical interaction between p14 ARF and MDM2 is in large part responsible for the ability of $\mathrm{p} 14^{\mathrm{ARF}}$ to stabilize and activate p53. p14 $14^{\mathrm{ARF}}$ prevents MDM2 from targeting p53 for degradation by inhibiting the E3 ubiquitin ligase activity of $\mathrm{MDM}^{28}$ and by blocking nuclear export of MDM2 and p53. ${ }^{29,30}$ It has also been firmly established that $\mathrm{p} 14^{\mathrm{ARF}}$, which is predominantly a nucleolar protein, is capable of mobilizing MDM2 into the nucleolus, and it has, therefore, been proposed that $\mathrm{p} 14^{\mathrm{ARF}}$ releases nucleoplasmic p53 from the inhibitory grip of MDM2 by inducing nucleolar sequestration of MDM2.30,31 Although MDM2 redistribution to nucleoli may contribute to p14 ${ }^{\mathrm{ARF}}$. induced p53 activity, several reports indicate that neither localization of $\mathrm{p} 14^{\mathrm{ARF}}$ in the nucleolus nor nucleolar sequestration of MDM2 is essential for stabilization and activation of $\mathrm{p} 53$ by $\mathrm{p} 14^{\mathrm{ARF}} \cdot{ }^{32-35} \mathrm{In}$ this regard, it has been suggested that $\mathrm{p} 14^{\mathrm{ARF}}$ is stored within the nucleolus in complexes with nucleophosmin, regulating ribosome biogenesis, and displaced to the nucleoplasm by stress-induced nucleolar perturbation, in which it can efficiently counteract MDM2 and activate the $\mathrm{p} 53$ pathway. ${ }^{34-36}$ In addition, p14 ${ }^{\mathrm{ARF}}$ may also enhance p53 function by MDM2-independent mechanisms, for example by inhibiting the activity of another E3 ubiquitin ligase involved in $\mathrm{p} 53$ degradation, ARF-BP1/Mule ${ }^{37}$ and by neutralizing the p53-antagonizing NF- $\kappa$ B pathway. ${ }^{38}$ The mechanisms by which $\mathrm{p} 14^{\mathrm{ARF}}$ promotes $\mathrm{p} 53$ stability and activity are shown in Figure 2.

Not surprisingly, many forms of cancer develop defects in MDM2 or p14 ARF to escape from p53 control. Genetic aberrations of the MDM2 locus as well as genetic or epigenetic disruption of the CDKN2A ( $\left.116^{I N K 4 a} / p 14^{A R F}\right)$ locus may account for inactivation of the p53 pathway in a subset of neuroblastoma tumors, mainly at relapse. Amplification of chromosome 12q-derived sequences encompassing the MDM2 gene has been described almost exclusively in neuroblastoma tumors and cell lines that simultaneously have 


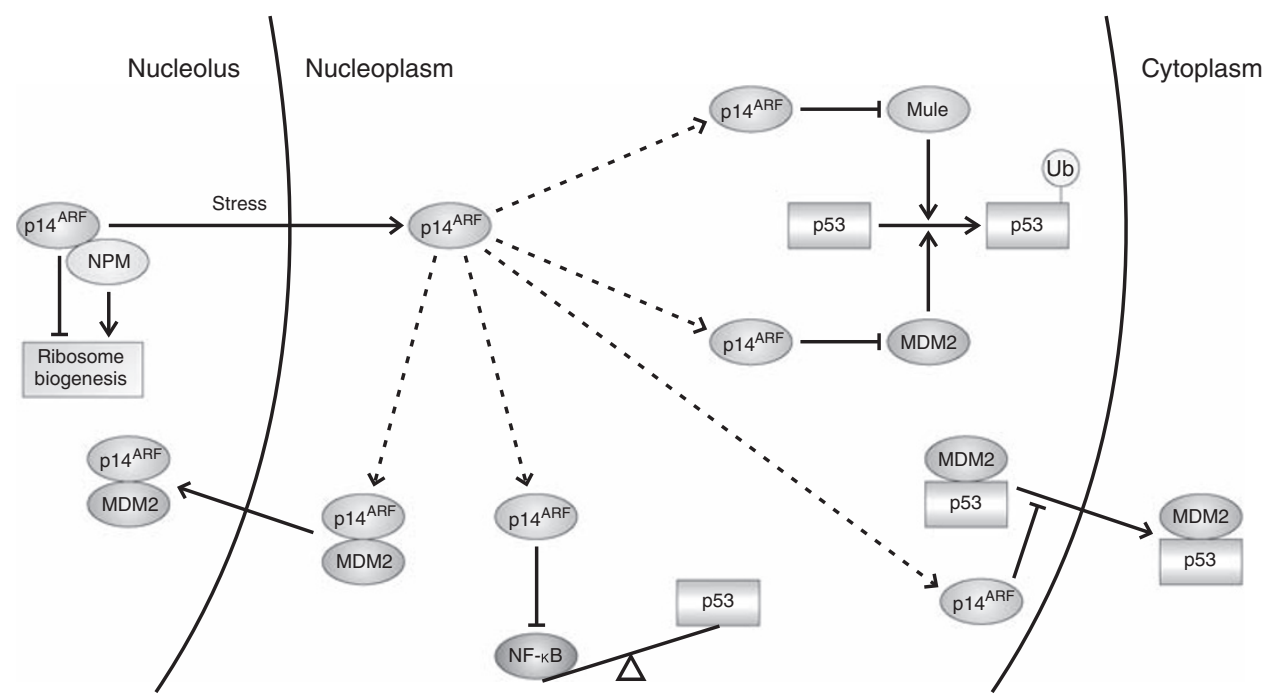

Figure 2 Schematic diagram of $\mathrm{p} 53$ stabilization and activation by $\mathrm{p} 14^{\mathrm{ARF}}$. The $\mathrm{p} 14^{\mathrm{ARF}}$ protein is predominantly localized to the nucleolus, in which it is stabilized by binding to nucleophosmin within maturing pre-ribosomal particles, pointing to a function in the regulation of ribosome biogenesis. Nucleophosmin promotes the processing of ribosomal RNA precursors and the nuclear export of ribosomal subunits, whereas overexpression of p14 ${ }^{\mathrm{ARF}}$ or its murine homolog p19 $9^{\mathrm{ARF}}$ interferes with transcription and processing of ribosomal RNA, impedes nucleocytoplasmic shuttling of nucleophosmin, and inhibits ribosome nuclear export. However, the precise biological function of the nucleophosmin-p14 ${ }^{\mathrm{ARF}}$ complexes remains a subject of debate. Stress signals trigger the disruption of the interaction between p14 ${ }^{\mathrm{ARF}}$ and nucleophosmin, and induce translocation of $\mathrm{p} 14^{\mathrm{ARF}}$ to the nucleoplasm. This redistribution enables $\mathrm{p} 14^{\mathrm{ARF}}$ to interact with p53-bound MDM2 and to antagonize MDM2 function by inhibiting its E3 ubiquitin ligase activity and by blocking nucleocytoplasmic shuttling of MDM2 and p53, resulting in p53 stabilization. The p53-inhibitory activity of MDM2 may also be neutralized by p14 ${ }^{\mathrm{ARF}}$-mediated mobilization of MDM2 into the nucleolus, although this mechanism is not strictly required for the p53-dependent functions of p14 ${ }^{\mathrm{ARF}}$. Furthermore, the $\mathrm{p}_{14}{ }^{\mathrm{ARF}}$ protein is capable of inhibiting the activity of another E3 ubiquitin ligase that targets p53 for degradation, ARF-BP1/Mule, and of counteracting the p53-antagonizing NF- $\kappa$ B pathway. It should be noted that $p 14^{A R F}$ also exerts a potent tumor suppressor activity independently of $p 53$, which is not illustrated in this figure. Mule, ARF-BP1/Mule; NPM, nucleophosmin; Ub, ubiquitin. The color reproduction of this figure is available on the html full text version of the manuscript

amplification of the MYCN oncogene on chromosome $2 \mathrm{p} 24$, and is associated with attenuated p53 transcriptional function and multidrug resistance..$^{5,39-43}$ The CDKN2A (p16 $6^{\text {INK4a }}$ ) $p 14^{A R F}$ ) locus at $9 p 21$ is the most frequent target of homozygous deletion in both neuroblastoma cell lines ${ }^{44}$ and primary tumors, ${ }^{45}$ and has been found to be silenced by methylation in several neuroblastoma cell lines. ${ }^{46,47}$ It has been estimated that approximately half of all neuroblastoma cell lines established at relapse are subject to a genetic or epigenetic lesion of the MDM2 or CDKN2A $\left(p 16^{I N K 4 a} / p 14^{A R F}\right)$ locus, ${ }^{6}$ but these findings await confirmation in a study that takes also neuroblastoma tumor samples into account.

A recent line of evidence supporting a role for MDM2 activity in the development and malignant behavior of neuroblastoma stems from epidemiological studies of a $\mathrm{T}>\mathrm{G}$ single nucleotide polymorphism in the MDM2 promoter (SNP309; rs2279744). The presence of this polymorphism increases the affinity of the MDM2 promoter for a transcriptional activator, Sp1. This results in enhanced transcription of MDM2, overexpression of the MDM2 protein, attenuation of the p53 pathway, and may eventually lead to accelerated tumor formation. ${ }^{48}$ Both individuals homozygous for SNP309 $(G / G)$ and subjects heterozygous for SNP309 (T/G) have an increased risk for the development of neuroblastoma, and neuroblastoma patients carrying the SNP309 variant (G/G or $\mathrm{T} / \mathrm{G}$ ) present with a more advanced clinical stage and have a shorter 5-year overall survival than patients homozygous for the wild-type allele $(\mathrm{T} / \mathrm{T}) .{ }^{49} \mathrm{~A}$ survival study in children with stage 4 neuroblastoma yielded similar results, with patients homozygous for SNP309 (G/G) having a worse overall survival and a worse survival after relapse than those homozygous for the wild-type allele $(\mathrm{T} / \mathrm{T})$, and with heterozygous SNP309 variant carriers (T/G) showing intermediate survival rates. ${ }^{50}$ These findings suggest that an increased activity of MDM2 because of the presence of SNP309 has an adverse effect on the development, aggressiveness, and outcome of neuroblastoma, and provide a direct incentive for the development of novel therapeutic strategies aimed at MDM2 inhibition.

\section{Transactivation of MDM2 Expression by MYCN}

Amplification of the $M Y C N$ oncogene plays a central role in the pathophysiology and clinical behavior of high-risk neuroblastoma. This genetic aberration is found in approximately $22 \%$ of all neuroblastoma tumors ${ }^{51}$ and is highly correlated with advanced stages of disease, rapid progression, treatment failure, and fatal outcome. ${ }^{52,53}$ MYCN amplification results in overexpression of the MYCN protein, which is a bHLH transcription factor that operates in a heterodimeric complex with Max family proteins to promote cell growth and proliferation. ${ }^{54}$ The oncogenic effects of $M Y C N$ overexpression have been convincingly established in a variety of model systems. Enhanced expression of $M Y C N$ elicits neoplastic transformation of mammalian cells, ${ }^{55,56}$ induces autocrine growth factor activity and increases proliferative potential, ${ }^{57}$ accelerates cell-cycle progression, ${ }^{58}$ enhances tumor cell motility and invasiveness, ${ }^{59}$ evokes genomic instability through disruption of the regulation of centrosome replication, ${ }^{60,61}$ diminishes expression of angiogenesis 
inhibitors, ${ }^{62,63}$ and promotes immune escape in neuroblastoma by inhibiting the chemoattraction of natural killer T cells. ${ }^{64}$ Direct evidence for a causative role of $M Y C N$ amplification in the pathogenesis of neuroblastoma is derived from the observation that transgenic mice with targeted expression of $M Y C N$ in normal neuroblasts develop tumors with a phenotype very similar to human neuroblastoma. ${ }^{65}$

However, aberrant $M Y C N$ expression also potently sensitizes neuroblastoma cells to drug- and stress-induced apoptosis, ${ }^{66-69}$ and, therefore, needs to be accompanied by a collateral impairment of the cell death program to provide a selective advantage for the tumor. This counterbalance to the intrinsic apoptosis-sensitizing effect of MYCN may be delivered by an increased activity of MDM2. A ChIP cloning approach combined with oligonucleotide pull-down and luciferase reporter assays has identified MDM2 as a direct transcriptional target of MYCN in neuroblastoma cells. ${ }^{70}$ In the same study, endogenous MDM2 mRNA and MDM2 protein levels were rapidly upregulated on induction of $M Y C N$ in $M Y C N$-conditional neuroblastoma cell lines, whereas targeted inhibition of MYCN in $M Y C N$-amplified neuroblastoma cells resulted in reduced MDM2 levels with stabilization of p53 and induction of apoptosis. These data suggest that MYCNdriven expression of MDM2 may constitutively debilitate the p53 pathway in $M Y C N$-amplified neuroblastoma cells, providing both a possible mechanism for evasion of MYCN-primed apoptosis and an explanation for the low frequency of TP53 mutations in these cells. This view is further strengthened by evidence that the closely related MYC (c-MYC) oncoprotein also relies on MDM2 to restrain p53-mediated apoptosis, as Myc-induced lymphomagenesis in mice is profoundly suppressed by haploinsufficiency of $M d m 2$ because of a drastic increase in p53-dependent apoptosis. ${ }^{71}$

\section{Suppression of $\mathrm{p} 14^{\mathrm{ARF}}$ and $\mathrm{p} 53$ by TWIST1}

Another excellent candidate to explain escape from MYCNdependent apoptotic sensitization is TWIST1. Just like MYCN, TWIST1 is a bHLH transcription factor with a fundamental role in embryonic and fetal development. This evolutionary conserved protein is involved in mesoderm formation and diversification, myogenesis, neurogenesis, and neural crest cell migration and differentiation. ${ }^{72}$ Loss-offunction mutations in the TWIST1 gene have been identified as the main cause of the Saethre-Chotzen syndrome, an autosomal dominant disorder of craniosynostosis with craniofacial and limb abnormalities. ${ }^{73,74}$ In addition to its developmental function in mesodermal and neural crest cell populations, TWIST1 also acts as an oncoprotein in several cancer types. Neuroblastoma tumors with $M Y C N$ amplification consistently exhibit MYCN-driven overexpression of TWIST1, resulting in an oncogenic cooperation that protects neuroblastoma cells from the proapoptotic effect of MYCN and that increases tumorigenicity in vivo. ${ }^{75}$ It could be shown that the protective effect conferred by TWIST1 was due to suppression of the p53 response and that the dampened p53 function was at least partially attributable to impaired $\mathrm{p} 14^{\mathrm{ARF}}$ activity. ${ }^{75}$ These findings are in agreement with an earlier study that pointed to downregulation of $\mathrm{p} 19^{\mathrm{ARF}}$ expression by Twist 1 as a mechanism for compensating the apoptosis-priming properties of Myc. ${ }^{76}$ Several other mechanisms may also contribute to the p53-inhibitory activity of TWIST1, including inhibition of acetyltransferases that serve as transcriptional coactivators for $\mathrm{p} 53,{ }^{77}$ modulation of the activity of a transactivator of the TP53 promoter, ${ }^{78}$ prevention of p53 phosphorylation, ${ }^{78}$ and direct suppression of the DNA-binding activity of $p 53 .{ }^{79}$ Of note, the TWIST1 and TWIST2 proteins have also recently been shown to prevent oncogene-induced premature senescence with concomitant abrogation of $\mathrm{p} 16^{\mathrm{INK} 4 \mathrm{a}}$ and $\mathrm{p} 21^{\mathrm{WAF} 1 / \mathrm{CIP} 1}$ activation, and to induce, in cooperation with activated mitogenic oncoproteins, epithelial-mesenchymal transition, suggesting a role as general inhibitors of multiple oncogene-induced safeguard programs. $^{80}$

\section{Inactivation of the p14 ${ }^{\mathrm{ARF}}$-p53 Pathway by BMI1}

The Polycomb-group transcriptional repressor BMI1 has been proposed as another roadblock to $\mathrm{MYCN}$-induced apoptosis by suppressing the p14 ${ }^{\mathrm{ARF}}$-p53 signaling pathway. ${ }^{81,82}$ BMl1 is a component of the Polycomb repressive complex 1, which mediates transcriptional silencing through chromatin modifications and which is involved in embryonic and adult stem cell maintenance and in the development of several cancer types. ${ }^{83}$ It has been convincingly shown that Bmi1 is indispensable for the self-renewal capacity and postnatal maintenance of hematopoietic and neural stem cells in mice by repressing the Cdkn2a $\left(p 16^{I N K 4 a} / p 19^{A R F}\right)$ locus. ${ }^{84-88}$ Notably, Bmi1 also collaborates strongly with Myc in murine lymphomagenesis, ${ }^{89-92}$ and the molecular basis of this oncogenic cooperation is the ability of Bmi1 to prohibit Myc-induced apoptosis by downregulating Cdkn2a ( $p 16^{\text {INK4a }}$ p19 ${ }^{A R F}$ ) expression. ${ }^{93}$ Similar to TWIST1, the BMI1 oncoprotein inhibits oncogene-induced premature senescence and cooperates with activated $\mathrm{H}$-Ras to induce neoplastic transformation and epithelial-mesenchymal transition. ${ }^{84,94}$ Thus, both the TWIST1 and BMI1 transcriptional regulators may overcome several oncogene-induced failsafe barriers and may serve as examples of corrupt exploitation of normal developmental programs by tumor cells.

$B M I 1$ is strongly expressed in neuroblastoma cell lines and tumors, ${ }^{81,82}$ and has been shown to be essential for the tumorigenicity of neuroblastoma cells. ${ }^{82}$ BMl1 negatively regulates p53 expression in neuroblastoma cells, potently inhibits the apoptotic activity of MYCN, and functions as an oncogenic partner of MYCN in the transformation of normal neural crest cells and in the malignant progression of neuroblastoma cells. ${ }^{82}$ These findings have been attributed to the ability of BMI1 to repress the CDKN2A (p16 ${ }^{I N K 4 a}$ ) p14 ${ }^{A R F}$ ) locus, although it cannot be excluded that CDKN2Aindependent pathways may also play a role. Interestingly, the collaborative activity between MYCN and BMI1 may be switched on by a single initiating event, as deregulated E2F1 activity, which is a characteristic lesion in highly proliferative neuroblastoma tumors, ${ }^{95}$ is capable of directly driving the expression of both oncogenes. ${ }^{81,96}$ The role of BMI1 in neuroblastoma pathogenesis seems not to be limited to $M Y C N$-amplified tumors, as BMI1 is also expressed and required for tumorigenicity in neuroblastoma cells with a normal copy number of $M Y C N{ }^{82}$ In line with the requirement 
of BMI1 activity in self-renewal of neural stem cells, it has been argued that BMI1 may be of critical importance for the maintenance of neuroblastoma stem cells by regulating clonogenic self-renewal and multilineage differentiation, offering an attractive target for therapeutic intervention. ${ }^{97}$

\section{Repression of p14 ${ }^{\mathrm{ARF}}$-p53 Signaling by Loss of CHD5}

Escape from p53 surveillance in neuroblastoma cells may also be accomplished by the loss of another chromatinremodeling protein involved in transcriptional control of the $C D K N 2 A\left(p 16^{I N K 4 a} / p 14^{A R F}\right)$ locus. One of the most characteristic genomic lesions in neuroblastoma is deletion of the short arm of chromosome 1, which is found in 25 to $35 \%$ of primary neuroblastoma tumors and 80 to $90 \%$ of neuroblastoma cell lines. ${ }^{98}$ The actual target of this deletion has remained elusive for a long time, but detailed analysis of the different genes located in the smallest region of deletion at 1 p36.31 has recently identified $C H D 5$ as the strongest candidate tumor suppressor gene. ${ }^{99,100} \mathrm{CHD} 5$ encodes a protein with chromatin-organizing modulator (chromo), helicase, and DNA-binding motifs that is preferentially expressed in the nervous system and the adrenal gland. ${ }^{101}$ Expression of CHD5 is very low or absent in neuroblastoma cell lines and is inversely correlated with $1 \mathrm{p}$ deletion, $M Y C N$ amplification, advanced clinical stage, unfavorable histology, and poor eventfree and overall survival in neuroblastoma tumors. ${ }^{99-101}$ Homozygous deletion and mutational inactivation of $\mathrm{CHD} 5$ are infrequent events, ${ }^{99}$ but it has been shown that the remaining $\mathrm{CHD} 5$ allele in neuroblastoma cells with heterozygous $1 p$ deletion may be transcriptionally silenced by promoter methylation. ${ }^{100}$ Reintroduction of $\mathrm{CHD5}$ in such neuroblastoma cells with $1 \mathrm{p}$ deletion and epigenetic CHD5 silencing significantly reduced clonogenicity and in vivo tumorigenicity, validating $\mathrm{CHD5}$ as a bona fide tumor suppressor gene. ${ }^{100}$

Of note, an independent study that used chromosome engineering to produce mouse strains with deletions or duplications of a region corresponding to human 1p36 identified $C h d 5$ as a potent tumor suppressor that controls proliferation, senescence, and apoptosis through the p19ARF. p53 pathway. ${ }^{102}$ Silencing of Chd5 by short hairpin RNA in MEFs severely compromised p53 function and promoted tumorigenesis, and these effects were associated with a substantial reduction in the basal and oncogene-induced expression levels of $\mathrm{p} 16^{\mathrm{INK} 4 a}$ and $\mathrm{p} 19^{\mathrm{ARF}}$. Knockdown of p19 $19^{A R F}$, but not $p 16^{\text {INK4a }}$, was capable of bypassing the proliferation defect of MEFs that harbored an engineered duplication of the 1p36-syntenic region, indicating that Chd5, which could be shown to be responsible for the proliferationsuppressive properties of the 1p36-syntenic region, exerts its antiproliferative activity by facilitating expression of $\mathrm{p} 19^{\mathrm{ARF}}$. Altogether, the findings of this study support a model in which the chromatin-remodeling activity of Chd5 is required for proper transcriptional activation of the Cdkn2a ( $p 16^{\text {INK4a }}$ $p 19^{A R F}$ ) locus. Although a direct link between CHD5 and the $14^{A R F}-p 53$ network remains to be established in the context of human neuroblastoma, it is tempting to speculate that loss of $\mathrm{CHD} 5$ by $1 \mathrm{p}$ deletion and epigenetic silencing may promote the pathogenesis of neuroblastoma by crippling the p14 ${ }^{\mathrm{ARF}}$-p53 signaling pathway.

\section{Deregulation of the p14 ${ }^{\mathrm{ARF}}$-MDM2-p53 Axis by PPM1D (Wip1)}

The most frequent and the prognostically most unfavorable genomic alteration in neuroblastoma is gain or amplification of genetic material from the long arm of chromosome $17 . .^{103,104}$ A gene at 17q23.2 encoding a key negative regulator of $p 53$, $P P M 1 D$, has been put forward as the most likely target of $17 q$ gain/amplification, based on its location in the minimal common region of gain/amplification, its consistent pattern of overexpression in neuroblastoma cell lines with 17q gain/ amplification, its growth-promoting and antiapoptotic activity in neuroblastoma cells, and the adverse impact of its expression level on the prognosis of primary neuroblastoma. ${ }^{105}$ Similarly, $P P M 1 D$ has been blamed as the culprit oncogene behind gain or amplification of $17 q 23$ in breast cancer, ${ }^{106-108}$ ovarian clear cell adenocarcinoma, ${ }^{109}$ and medulloblastoma. ${ }^{110,111}$

The protein encoded by PPM1D is a serine/threonine phosphatase that is transcriptionally induced by wild-type p53 in response to DNA-damaging stimuli such as ionizing radiation, and it has, therefore, been given the name Wip1 (wild-type p53-induced phosphatase 1). ${ }^{112}$ The p53-dependent expression of Wip1 creates a negative feedback loop that helps to turn off p53 at the end of a stress response, as Wip1 suppresses p53 activity and stability through multiple mechanisms (Figures 3a-c). First, Wip1 dephosphorylates and inactivates several kinases that mediate p53 stabilization and activation after genotoxic stress, for example p38 MAPK, ${ }^{113}$ Chk1, ${ }^{114}$ Chk2, ${ }^{115-117}$ ATM,${ }^{118,119}$ and probably ATR. $^{120}$ In addition, Wip1 dephosphorylates p53 itself at serine 15 , thereby probably promoting both p53 degradation and inactivation. ${ }^{114}$ The most important block provided by Wip1 on p53 function is mediated through stabilization and enhanced p53 binding of MDM2, which result from Wip1induced dephosphorylation of MDM2 at serine 395 and which argue for a role of Wip1 as a molecular gatekeeper in the p53MDM2 autoregulatory feedback loop. ${ }^{121}$ Finally, studies using Ppm1d-null MEFs have shown that Wip1 is also capable of suppressing p19 ${ }^{\mathrm{ARF}}$ levels through a p38 MAPK-dependent mechanism, which seems to involve transcriptional repression of the Cdkn2a ( $\left.p 16^{I N K 4 a} / p 19^{A R F}\right)$ locus, thus offering an additional explanation of how Wip1 may keep p53 in check. $^{122}$

The potent inhibitory activity of Wip 1 on p53 provides, in principle, an appealing opportunity for tumor cells to escape from p53 control. Indeed, as discussed above, copy number gain/amplification and overexpression of PPM1D are observed in a variety of human tumors including neuroblastoma, which then typically retain wild-type p53 and often carry a poor prognosis. ${ }^{105,107-110}$ Overexpression experiments have shown that Wip1 induces malignant transformation in collaboration with other oncogenes, protects against oncogene-induced premature senescence and apoptosis, and accelerates tumorigenesis in vivo. ${ }^{106,107,123,124}$ Conversely, Ppm1d-null MEFs and mice are resistant to oncogene-induced transformation and to spontaneous 
a

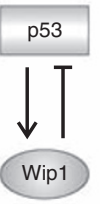

b

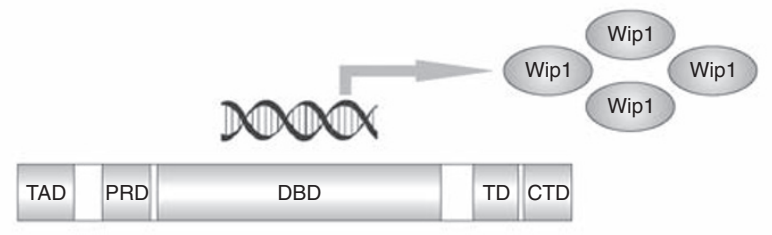

C

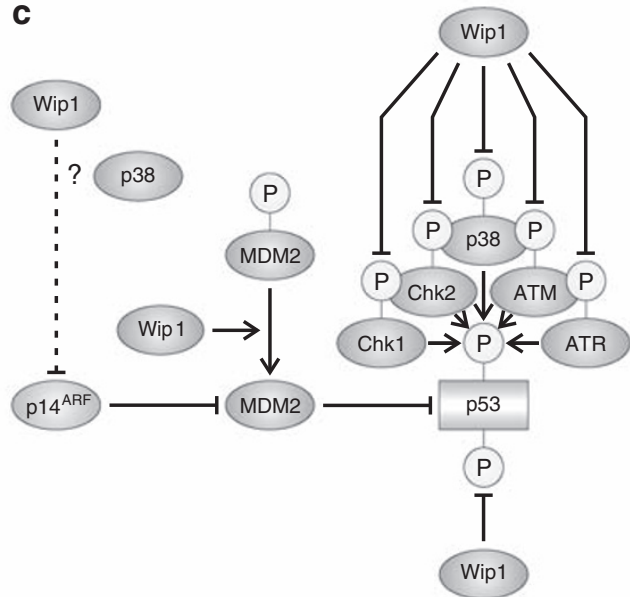

Figure 3 The p53-Wip1 autoregulatory feedback loop. (a) The p53-inducible expression of Wip1 sets up a negative feedback loop that helps to restrain p53 at the end of a stress response. (b) Binding of p53 to a response element in the $5^{\prime}$ untranslated region of the PPM1D (WIP1) gene results in transcriptional activation and expression of Wip1 after exposure to DNA damage and other environmental stresses. The domain structure of p53 is shown schematically: TAD, transactivation domain, amino acids 1-40; PRD, proline-rich domain, amino acids 61-94; DBD, DNA-binding domain, amino acids 100-300; TD, tetramerization domain, amino acids 324-355; CTD, C-terminal regulatory domain, amino acids 360-393. (c) Wip1 is a phosphatase that negatively regulates p53 activity and stability by several mechanisms, including dephosphorylation and inactivation of p53-targeting kinases (p38 MAPK, Chk1, Chk2, ATM, and probably ATR), dephosphorylation of p53 itself, and dephosphorylation of MDM2. The latter activity of Wip1 stabilizes MDM2 and facilitates its access to $\mathrm{p53}$, and has been proposed to be the most important contributor to the p53-inhibitory effect of Wip1. In addition, Wip1 may also decrease the expression of p14 ${ }^{\mathrm{ARF}}$ through a p38 MAPK-dependent, but incompletely understood mechanism. P, phosphate group; p38, p38 MAPK. The color reproduction of this figure is available on the html full text version of the manuscript

and oncogene-driven tumorigenesis, respectively. ${ }^{119,122,123}$ Although most of the oncogenic properties of Wip1 are ascribed to its ability to suppress the p53 pathway and the DNA damage response, concomitant inhibition of $\mathrm{pRb}$ tumor suppressor activity because of transcriptional repression of p16 ${ }^{\text {INK4a }}$ expression may also play a role. ${ }^{122}$ Of note in the context of neuroblastoma is the observation that homozygous or heterozygous deficiency of Ppm1d in mice confers protection against Myc-induced lymphomagenesis in a p53and ATM-dependent manner, indicative of a strict requirement for Wip1 activity in the suppression of Myc-triggered apoptosis. ${ }^{119}$ This is reminiscent of the critical role of Mdm2 in evasion of Myc-primed apoptosis in murine lymphomagenesis, ${ }^{71}$ which is a concept directly transferable to human neuroblastoma and MYCN. ${ }^{70}$ It could, therefore, be speculated that increased dosage of $P P M 1 D$ provides another mechanism for escape from MYCN-stimulated apoptosis and a molecular explanation for the strong association between $17 q$ gain and $M Y C N$ amplification in neuroblastoma cells. ${ }^{105}$

\section{Cytoplasmic Sequestration of p53}

Aberrant cytoplasmic localization of wild-type p53 has been proposed as another mechanism for p53 inactivation in neuroblastoma cells. Although controversy exists on the frequency and functional relevance of this phenomenon, it has been extensively documented that cytoplasmic p53 sequestration does occur in at least some cases of neuroblastoma. Interestingly, as will be discussed below, cumulating evidence indicates that an increased activity of MDM2 or a dysfunction of its functional counterpart HAUSP, a principal p53-deubiquitinating enzyme, lies at the molecular basis of cytoplasmic p53 retention in neuroblastoma, further under- scoring the importance of MDM2 deregulation as a means to escape from p53 control.

An initial study found cytoplasmic p53 sequestration in $96 \%$ of undifferentiated neuroblastoma tumors, whereas this phenotype was absent in differentiated neuroblastoma tumors. ${ }^{125}$ However, other studies have reported a predominant nuclear localization of p53 in undifferentiated neuroblastoma tumors, and both cytoplasmic and nuclear p53 in differentiating neuroblastoma. ${ }^{9,43,126}$ Conflicting results also exist for neuroblastoma cell lines, as the subcellular localization of p53 has been reported to be exclusively cytoplasmic (e.g. in IMR-32 and SK-N-SH cells), ${ }^{127}$ primarily cytoplasmic and weakly nuclear (e.g. in IMR-32 and SK-N-SH cells), ${ }^{126,128}$ equally cytoplasmic and nuclear (e.g. in SK-N-SH cells), ${ }^{7}$ predominantly nuclear (e.g. in IMR-32 cells), ${ }^{43}$ and completely nuclear (e.g. in IMR-32 and SK-N-SH cells). ${ }^{129}$ Some of the discrepancies may be explained by cross-reactivity of the antibodies used to detect p53 and by different methods of tissue fixation and cell preparation..$^{9,43,126}$ Nonetheless, it is generally accepted that some cytoplasmic p53 does exist in neuroblastoma, although the prevalence and importance of cytoplasmic p53 sequestration remain a subject of debate. $^{9,130}$ It has been reported that abnormal cytoplasmic p53 localization may attenuate the DNA damage-induced $\mathrm{G}_{1}$ checkpoint function ${ }^{127}$ and the apoptotic activity ${ }^{131,132}$ of wildtype p53 in some neuroblastoma cells. On the contrary, many studies have shown that the DNA-binding and transactivation capacity of $\mathrm{p} 53$ and the $\mathrm{p} 53$ signal transduction pathway are intact in neuroblastoma cells with wild-type p53, $1,4,7-9$ indicating that cytoplasmic retention of wild-type p53 is either an infrequent anomaly or a relative block on p53 that can be overcome by appropriate p53-inducing stimuli.

Proposed mechanisms for abnormal p53 accumulation in the cytoplasm of neuroblastoma cells include hyperactive 
nuclear export of p53, cytoplasmic tethering of p53, resistance of p53 to proteasomal degradation, and possibly impaired nuclear re-import of p53. A unifying theme common to these diverse mechanisms may be the involvement of a disrupted MDM2/HAUSP regulation of $p 53$. It has been firmly established that cytoplasmic p53 sequestration in neuroblastoma cells is at least in part caused by enhanced nuclear export ${ }^{133}$ and that MDM2 plays an important role in this nuclear exclusion of p53. ${ }^{131,134}$ Once transported to the cytoplasm, p53 may be held in this compartment by a cytoplasmic anchor protein, such as Parc. ${ }^{128}$ Neuroblastoma cells express high levels of Parc, which have been shown to prevent nuclear localization of $\mathrm{p} 53$ and a normal apoptotic response to the genotoxic drug etoposide. ${ }^{128}$ A comparable cytoplasmic anchoring function may be exerted by the large $\mathrm{T}$ antigen from human polyomavirus $\mathrm{BK},{ }^{135,136}$ by the glucocorticoid receptor, ${ }^{137}$ and by the MDM2-related protein MDM4 (also known as MDMX). ${ }^{138}$ It has also been shown that p53 in neuroblastoma cells is aberrantly ubiquitinated because of an impaired interaction between p53 and the deubiquitinating enzyme HAUSP, and that this hyperubiquitination contributes to cytoplasmic p53 sequestration. ${ }^{130}$ As both Parc and HAUSP interact with the carboxy terminus of p53, competition between Parc and HAUSP for p53 binding has been postulated to underly the impaired p53-HAUSP interaction in neuroblastoma cells, although this remains to be formally proven. ${ }^{130}$ The defective deubiquitination of $p 53$ results in the appearance of (multi)monoubiquitinated p53 species, which are relatively resistant to proteasomal degradation ${ }^{139}$ and which are subject to increased nuclear export and possibly to diminished re-import, thus yielding a phenotype of cytoplasmic p53 sequestration. ${ }^{130}$ In keeping with the deregulation of MDM2/HAUSP, interference with p53 hyperubiquitination by targeted inhibition of the p53-MDM2 interaction in neuroblastoma cells has been shown to relocate p53 from the cytoplasm to the nucleus and to restore the transcriptional and apoptotic activities of $p 53 .{ }^{130}$

\section{Conclusions}

The rarity of TP53 mutations in neuroblastoma has been a puzzling issue to many investigators given the potent antitumor capacity of wild-type p53 protein. A substantial number of alternative p53-inactivating lesions have been identified in neuroblastoma during the past few years, many of which interfere with proper functioning of the p14 ${ }^{\mathrm{ARF}}$-MDM2p53 axis (Figure 4). A recent mouse study underscores the importance of direct inhibition of p53 by MDM2 and suppression of $\mathrm{p} 19^{\mathrm{ARF}}$ in the pathogenesis of neuroblastoma. ${ }^{140}$ However, it should be kept in mind that cellular decisions of growth, survival, and death result from the integration of a complex network of intertwined signaling cascades and, therefore, that also pathways that do not impinge directly on the core p53 machinery may still provide a means to oppose or neutralize p53 activity. Full characterization of the nature and relative importance of the different blocks on the p53 pathway in neuroblastoma cells awaits genome-wide experimental approaches in well-controlled model systems.

It may not be that surprising, after all, that turning off the p14 ${ }^{\mathrm{ARF}}$-MDM2-p53 axis is a preferential mode of p53

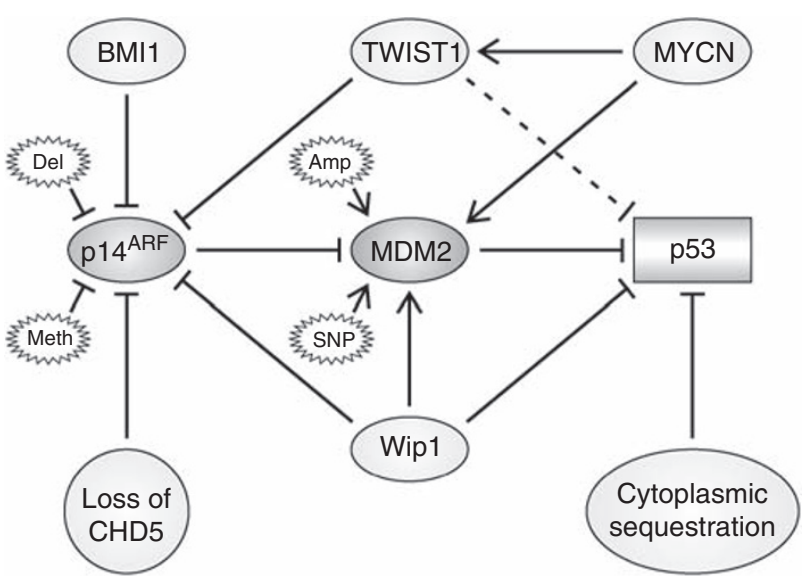

Figure 4 Mechanisms by which neuroblastoma cells escape from p53mediated growth control. A variety of lesions that result in inactivation of $p 14^{\mathrm{ARF}}$ or increased activity of MDM2 may provide a molecular explanation for the low frequency of TP53 mutations in neuroblastoma cells (see text for details). Amp, amplification; Del, deletion; Meth, methylation; SNP, SNP309 in the MDM2 gene. The color reproduction of this figure is available on the html full text version of the manuscript

inactivation in neuroblastoma cells. It has been convincingly shown that deregulated $M Y C$ expression is a potent trigger for induction of the $\mathrm{p} 14^{\mathrm{ARF}}$ protein, and it is very likely that the same holds true for $M Y C N .^{25,141}$ In addition, aggressive neuroblastoma tumors typically express high levels of the E2F1 transcription factor, ${ }^{95}$ which is capable of inducing p14 ${ }^{\mathrm{ARF}}$ expression through binding to an E2F-responsive element in the $p 14^{A R F}$ promoter. ${ }^{142,143}$ Hence, acquisition of defects that inactivate $\mathrm{p} 14^{\mathrm{ARF}}$ or that uncouple $\mathrm{p} 14^{\mathrm{ARF}}$ from its p53-dependent effector pathway (i.e. through uncontrolled MDM2 activity) may provide the most effective route to nonmutational p53 inactivation in neuroblastoma cells by directly dismantling the molecular circuitry that signals the malicious identity of these cells to the p53 guardian.

In conclusion, it has become increasingly clear in recent years that inappropriately increased activity of MDM2 is the primary culprit for p53 inactivation in neuroblastoma cells. Preclinical work from our laboratory and others has shown that small-molecule MDM2 inhibitors are capable of eliciting potent antitumor effects against neuroblastoma by selectively and non-genotoxically reactivating p53. $8,130,144,145$ These findings may provide a new therapeutic avenue for the treatment of children with high-risk neuroblastoma.

Acknowledgements. The p53 work in our laboratory is supported by the Research Foundation - Flanders (FWO; grants G.0198.08 and G.0225.09), Cycle for Life - Belgium, the Centrum voor Studie en Behandeling van Gezwelziekten - Ghent, and the Ghent Childhood Cancer Fund. TVM is a research assistant from the FWO (grant 011F4004). AR is supported by a grant from the Emmanuel van der Schueren Foundation.

1. Tweddle DA, Pearson AD, Haber M, Norris MD, Xue C, Flemming $C$ et al. The p53 pathway and its inactivation in neuroblastoma. Cancer Lett 2003; 197: 93-98.

2. Tweddle DA, Malcolm AJ, Bown N, Pearson AD, Lunec J. Evidence for the development of p53 mutations after cytotoxic therapy in a neuroblastoma cell line. Cancer Res 2001; 61: 8-13.

3. Kotchetkov R, Driever PH, Cinatl J, Michaelis M, Karaskova J, Blaheta R et al. Increased malignant behavior in neuroblastoma cells with acquired multi-drug resistance does not depend on P-gp expression. Int J Oncol 2005; 27: 1029-1037. 
4. Xue C, Haber M, Flemming C, Marshall GM, Lock RB, MacKenzie KL et al. p53 determines multidrug sensitivity of childhood neuroblastoma. Cancer Res 2007; 67: 10351-10360.

5. Keshelava N, Zuo JJ, Chen P, Waidyaratne SN, Luna MC, Gomer CJ et al. Loss of p53 function confers high-level multidrug resistance in neuroblastoma cell lines. Cancer Res 2001; 61: 6185-6193.

6. Carr J, Bell E, Pearson AD, Kees UR, Beris $\mathrm{H}$, Lunec $\mathrm{J}$ et al. Increased frequency of aberrations in the p53/MDM2/p14 ${ }^{A R F}$ pathway in neuroblastoma cell lines established at relapse. Cancer Res 2006; 66: 2138-2145.

7. Goldman SC, Chen CY, Lansing TJ, Gilmer TM, Kastan MB. The p53 signal transduction pathway is intact in human neuroblastoma despite cytoplasmic localization. Am J Pathol 1996; 148: 1381-1385.

8. Van Maerken T, Speleman F, Vermeulen J, Lambertz I, De Clercq S, De Smet E et al. Small-molecule MDM2 antagonists as a new therapy concept for neuroblastoma. Cancer Res 2006; 66: 9646-9655.

9. Chen L, Malcolm AJ, Wood KM, Cole M, Variend S, Cullinane C et al. p53 is nuclear and functional in both undifferentiated and differentiated neuroblastoma. Cell Cycle 2007; 6 : 2685-2696.

10. Cahilly-Snyder L, Yang-Feng T, Francke U, George DL. Molecular analysis and chromosomal mapping of amplified genes isolated from a transformed mouse 3T3 cell line. Somat Cell Mol Genet 1987; 13: 235-244.

11. Marine JC, Francoz S, Maetens M, Wahl G, Toledo F, Lozano G. Keeping p53 in check: essential and synergistic functions of Mdm2 and Mdm4. Cell Death Differ 2006; 13: 927-934.

12. Vousden KH, Lu X. Live or let die: the cell's response to p53. Nat Rev Cancer 2002; 2 594-604.

13. Oliner JD, Pietenpol JA, Thiagalingam S, Gyuris J, Kinzler KW, Vogelstein B. Oncoprotein MDM2 conceals the activation domain of tumour suppressor p53. Nature 1993; 362: 857-860.

14. Thut CJ, Goodrich JA, Tjian R. Repression of p53-mediated transcription by MDM2: a dual mechanism. Genes Dev 1997; 11: 1974-1986.

15. Wadgaonkar R, Collins T. Murine double minute (MDM2) blocks p53-coactivator interaction, a new mechanism for inhibition of p53-dependent gene expression. $J$ Biol Chem 1999; 274: 13760-13767.

16. Kohn KW, Pommier Y. Molecular interaction map of the p53 and Mdm2 logic elements which control the Off On switch of p53 in response to DNA damage. Biochem Biophys Res Commun 2005; 331: 816-827.

17. Brooks CL, Gu W. p53 ubiquitination: Mdm2 and beyond. Mol Cell 2006; 21: 307-315.

18. Minsky N, Oren M. The RING domain of Mdm2 mediates histone ubiquitylation and transcriptional repression. Mol Cell 2004; 16: 631-639.

19. Xirodimas DP, Saville MK, Bourdon JC, Hay RT, Lane DP. Mdm2-mediated NEDD8 conjugation of p53 inhibits its transcriptional activity. Cell 2004; 118: 83-97.

20. Ito A, Kawaguchi Y, Lai CH, Kovacs JJ, Higashimoto Y, Appella E et al. MDM2-HDAC1mediated deacetylation of $p 53$ is required for its degradation. $E M B O J 2002 ; 21$ : $6236-6245$.

21. Mirnezami AH, Campbell SJ, Darley M, Primrose JN, Johnson PW, Blaydes JP. Hdm2 recruits a hypoxia-sensitive corepressor to negatively regulate p53-dependent transcription. Curr Biol 2003; 13: 1234-1239.

22. Sui G, Affar el B, Shi Y, Brignone C, Wall NR, Yin $P$ et al. Yin Yang 1 is a negative regulator of p53. Cell 2004; 117: 859-872.

23. Wang $\mathrm{C}$, Ivanov A, Chen L, Fredericks WJ, Seto E, Rauscher 3rd FJ et al. MDM2 interaction with nuclear corepressor KAP1 contributes to p53 inactivation. EMBO J 2005; 24: 3279-3290.

24. Lowe SW, Sherr CJ. Tumor suppression by Ink4a-Arf. progress and puzzles. Curr Opin Genet Dev 2003; 13: 77-83.

25. Sherr CJ. Divorcing ARF and p53: an unsettled case. Nat Rev Cancer 2006; 6: 663-673.

26. Efeyan A, Garcia-Cao I, Herranz D, Velasco-Miguel S, Serrano M. Tumour biology: policing of oncogene activity by p53. Nature 2006; 443: 159.

27. Christophorou MA, Ringshausen I, Finch AJ, Swigart LB, Evan GI. The pathological response to DNA damage does not contribute to p53-mediated tumour suppression. Nature 2006; 443: 214-217.

28. Honda R, Yasuda H. Association of $p 19^{A R F}$ with Mdm2 inhibits ubiquitin ligase activity of Mdm2 for tumor suppressor p53. EMBO J 1999; 18: 22-27.

29. Zhang $Y$, Xiong $Y$. Mutations in human ARF exon 2 disrupt its nucleolar localization and impair its ability to block nuclear export of MDM2 and p53. Mol Cell 1999; 3 : 579-591.

30. Tao W, Levine AJ. P19 ARF stabilizes p53 by blocking nucleo-cytoplasmic shuttling of Mdm2. Proc Natl Acad Sci USA 1999; 96: 6937-6941.

31. Weber JD, Taylor LJ, Roussel MF, Sherr CJ, Bar-Sagi D. Nucleolar Arf sequesters Mdm2 and activates p53. Nat Cell Biol 1999; 1: 20-26.

32. Midgley CA, Desterro JM, Saville MK, Howard S, Sparks A, Hay RT et al. An N-terminal p14 ${ }^{\mathrm{ARF}}$ peptide blocks Mdm2-dependent ubiquitination in vitro and can activate p53 in vivo. Oncogene 2000; 19: 2312-2323.

33. Lin AW, Lowe SW. Oncogenic ras activates the ARF-p53 pathway to suppress epithelial cell transformation. Proc Natl Acad Sci USA 2001; 98: 5025-5030.

34. Llanos S, Clark PA, Rowe J, Peters G. Stabilization of $\mathrm{p} 53$ by $\mathrm{p} 14^{\mathrm{ARF}}$ without relocation of MDM2 to the nucleolus. Nat Cell Biol 2001; 3: 445-452.
35. Korgaonkar C, Hagen J, Tompkins V, Frazier AA, Allamargot C, Quelle FW et al Nucleophosmin (B23) targets ARF to nucleoli and inhibits its function. Mol Cell Biol 2005; 25: 1258-1271.

36. Gjerset RA, Bandyopadhyay K. Regulation of p14ARF through subnuclear compartmentalization. Cell Cycle 2006; 5: 686-690.

37. Chen D, Kon N, Li M, Zhang W, Qin J, Gu W. ARF-BP1/Mule is a critical mediator of the ARF tumor suppressor. Cell 2005; 121: 1071-1083.

38. Rocha S, Campbell KJ, Perkins ND. p53- and Mdm2-independent repression of NF- $\kappa$ B transactivation by the ARF tumor suppressor. Mol Cell 2003; 12: 15-25.

39. Corvi R, Savelyeva L, Amler L, Handgretinger R, Schwab M. Cytogenetic evolution of MYCN and MDM2 amplification in the neuroblastoma LS tumour and its cell line. Eur $J$ Cancer 1995; 31A: 520-523.

40. Corvi R, Savelyeva L, Breit S, Wenzel A, Handgretinger R, Barak J et al. Non-syntenic amplification of MDM2 and MYCN in human neuroblastoma. Oncogene 1995; 10: $1081-1086$

41. Van Roy N, Forus A, Myklebost O, Cheng NC, Versteeg R, Speleman F. Identification of two distinct chromosome 12-derived amplification units in neuroblastoma cell line NGP. Cancer Genet Cytogenet 1995; 82: 151-154.

42. McKenzie PP, Guichard SM, Middlemas DS, Ashmun RA, Danks MK, Harris LC. Wildtype p53 can induce p21 and apoptosis in neuroblastoma cells but the DNA damage-induced $\mathrm{G}_{1}$ checkpoint function is attenuated. Clin Cancer Res 1999; 5 4199-4207.

43. Tweddle DA, Malcolm AJ, Cole M, Pearson AD, Lunec J. p53 cellular localization and function in neuroblastoma: evidence for defective $G_{1}$ arrest despite WAF1 induction in MYCN-amplified cells. Am J Pathol 2001; 158: 2067-2077.

44. Thompson PM, Maris JM, Hogarty MD, Seeger RC, Reynolds CP, Brodeur GM et al.

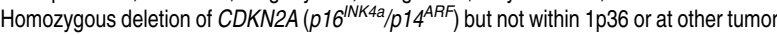
suppressor loci in neuroblastoma. Cancer Res 2001; 61: 679-686.

45. Caren H, Erichsen J, Olsson L, Enerback C, Sjoberg RM, Abrahamsson J et al. Highresolution array copy number analyses for detection of deletion, gain, amplification and copy-neutral LOH in primary neuroblastoma tumors: Four cases of homozygous deletions of the CDKN2A gene. BMC Genomics 2008; 9: 353

46. Takita J, Hayashi Y, Kohno T, Yamaguchi N, Hanada R, Yamamoto K et al. Deletion map of chromosome 9 and $p 16$ (CDKN2A) gene alterations in neuroblastoma. Cancer Res 1997; 57: 907-912

47. Takita J, Hayashi $\mathrm{Y}$, Nakajima $\mathrm{T}$, Adachi J, Tanaka T, Yamaguchi $\mathrm{N}$ et al. The p16 (CDKN2A) gene is involved in the growth of neuroblastoma cells and its expression is associated with prognosis of neuroblastoma patients. Oncogene 1998; 17 3137-3143.

48. Bond GL, Hu W, Bond EE, Robins H, Lutzker SG, Arva NC et al. A single nucleotide polymorphism in the MDM2 promoter attenuates the p53 tumor suppressor pathway and accelerates tumor formation in humans. Cell 2004; 119: 591-602.

49. Cattelani S, Defferrari R, Marsilio S, Bussolari R, Candini O, Corradini F et al. Impact of a single nucleotide polymorphism in the MDM2 gene on neuroblastoma development and aggressiveness: results of a pilot study on 239 patients. Clin Cancer Res 2008; 14 : 3248-3253

50. Perfumo C, Parodi S, Mazzocco K, Defferrari R, Inga A, Haupt R et al. Impact of MDM2 SNP309 genotype on progression and survival of stage 4 neuroblastoma. Eur J Cancer 2008; 44: 2634-2639.

51. Brodeur GM. Neuroblastoma: biological insights into a clinical enigma. Nat Rev Cancer 2003; 3: 203-216.

52. Brodeur GM, Seeger RC, Schwab M, Varmus HE, Bishop JM. Amplification of N-myc in untreated human neuroblastomas correlates with advanced disease stage. Science 1984; 224: 1121-1124.

53. Seeger RC, Brodeur GM, Sather H, Dalton A, Siegel SE, Wong KY et al. Association of multiple copies of the $\mathrm{N}$-myc oncogene with rapid progression of neuroblastomas. $N$ Eng J Med 1985; 313: 1111-1116.

54. Wenzel A, Schwab M. The mycN/max protein complex in neuroblastoma. Short review. Eur J Cancer 1995; 31A: 516-519.

55. Schwab M, Varmus HE, Bishop JM. Human N-myc gene contributes to neoplastic transformation of mammalian cells in culture. Nature 1985; 316: 160-162.

56. Small MB, Hay N, Schwab M, Bishop JM. Neoplastic transformation by the human gene N-myc. Mol Cell Biol 1987; 7: 1638-1645.

57. Schweigerer L, Breit S, Wenzel A, Tsunamoto K, Ludwig R, Schwab M. Augmented MYCN expression advances the malignant phenotype of human neuroblastoma cells: evidence for induction of autocrine growth factor activity. Cancer Res 1990; 50: 4411-4416.

58. Lutz W, Stohr M, Schurmann J, Wenzel A, Lohr A, Schwab M. Conditional expression of $\mathrm{N}$-myc in human neuroblastoma cells increases expression of $\alpha$-prothymosin and ornithine decarboxylase and accelerates progression into S-phase early after mitogenic stimulation of quiescent cells. Oncogene 1996; 13: 803-812.

59. Goodman LA, Liu BC, Thiele CJ, Schmidt ML, Cohn SL, Yamashiro JM et al. Modulation of $\mathrm{N}$-myc expression alters the invasiveness of neuroblastoma. Clin Exp Metastasis 1997; 15: $130-139$.

60. Sugihara E, Kanai M, Matsui A, Onodera M, Schwab M, Miwa M. Enhanced expression of MYCN leads to centrosome hyperamplification after DNA damage in neuroblastoma cells. Oncogene 2004; 23: 1005-1009. 
61. Slack AD, Chen Z, Ludwig AD, Hicks J, Shohet JM. MYCN-directed centrosome amplification requires MDM2-mediated suppression of p53 activity in neuroblastoma cells. Cancer Res 2007; 67: 2448-2455.

62. Fotsis T, Breit S, Lutz W, Rossler J, Hatzi E, Schwab M et al. Down-regulation of endothelial cell growth inhibitors by enhanced MYCN oncogene expression in human neuroblastoma cells. Eur J Biochem 1999; 263: 757-764.

63. Hatzi E, Breit S, Zoephel A, Ashman K, Tontsch U, Ahorn H et al. MYCN oncogene and angiogenesis: down-regulation of endothelial growth inhibitors in human neuroblastoma cells. Purification, structural, and functional characterization. Adv Exp Med Biol 2000; 476: 239-248.

64. Song L, Ara T, Wu HW, Woo CW, Reynolds CP, Seeger RC et al. Oncogene MYCN regulates localization of NKT cells to the site of disease in neuroblastoma. J Clin Invest 2007; 117: 2702-2712.

65. Weiss WA, Aldape K, Mohapatra G, Feuerstein BG, Bishop JM. Targeted expression of MYCN causes neuroblastoma in transgenic mice. EMBO J 1997; 16: 2985-2995.

66. Lutz W, Fulda S, Jeremias I, Debatin KM, Schwab M. MycN and IFN $\gamma$ cooperate in apoptosis of human neuroblastoma cells. Oncogene 1998; 17: 339-346.

67. Fulda S, Lutz W, Schwab M, Debatin KM. MycN sensitizes neuroblastoma cells for drug-induced apoptosis. Oncogene 1999; 18: 1479-1486.

68. Fulda S, Lutz W, Schwab M, Debatin KM. MycN sensitizes neuroblastoma cells for drug-triggered apoptosis. Med Pediatr Oncol 2000; 35: 582-584.

69. van Golen CM, Soules ME, Grauman AR, Feldman EL. N-Myc overexpression leads to decreased $\beta 1$ integrin expression and increased apoptosis in human neuroblastoma cells. Oncogene 2003; 22: 2664-2673.

70. Slack A, Chen Z, Tonelli R, Pule M, Hunt L, Pession A et al. The p53 regulatory gene MDM2 is a direct transcriptional target of MYCN in neuroblastoma. Proc Natl Acad Sc USA 2005; 102: 731-736.

71. Alt JR, Greiner TC, Cleveland JL, Eischen CM. Mdm2 haplo-insufficiency profoundly inhibits Myc-induced lymphomagenesis. EMBO J 2003; 22: 1442-1450.

72. Firulli $\mathrm{AB}$, Conway SJ. Phosphoregulation of Twist1 provides a mechanism of cell fate control. Curr Med Chem 2008; 15: 2641-2647.

73. Howard TD, Paznekas WA, Green ED, Chiang LC, Ma N, Ortiz de Luna RI et al. Mutations in TWIST, a basic helix-loop-helix transcription factor, in Saethre-Chotzen syndrome. Nat Genet 1997; 15: 36-41.

74. el Ghouzzi V, Le Merrer M, Perrin-Schmitt F, Lajeunie E, Benit P, Renier D et al. Mutations of the TWIST gene in the Saethre-Chotzen syndrome. Nat Genet 1997; 15: 42-46.

75. Valsesia-Wittmann S, Magdeleine M, Dupasquier S, Garin E, Jallas AC, Combaret V et al. Oncogenic cooperation between $\mathrm{H}$-Twist and $\mathrm{N}-\mathrm{Myc}$ overrides failsafe programs in cancer cells. Cancer Cell 2004; 6: 625-630.

76. Maestro R, Dei Tos AP, Hamamori Y, Krasnokutsky S, Sartorelli V, Kedes L et al. twist is a potential oncogene that inhibits apoptosis. Genes Dev 1999; 13: 2207-2217.

77. Hamamori Y, Sartorelli V, Ogryzko V, Puri PL, Wu HY, Wang JY et al. Regulation of histone acetyltransferases $\mathrm{p} 300$ and PCAF by the bHLH protein twist and adenoviral oncoprotein E1A. Cell 1999; 96: 405-413.

78. Stasinopoulos IA, Mironchik Y, Raman A, Wildes F, Winnard Jr P, Raman V. HOXA5-twist interaction alters $p 53$ homeostasis in breast cancer cells. J Biol Chem 2005; 280: 2294-2299.

79. Shiota M, Izumi H, Onitsuka T, Miyamoto N, Kashiwagi E, Kidani A et al. Twist and p53 reciprocally regulate target genes via direct interaction. Oncogene 2008; 27: 5543-5553.

80. Ansieau S, Bastid J, Doreau A, Morel AP, Bouchet BP, Thomas C et al. Induction of EMT by twist proteins as a collateral effect of tumor-promoting inactivation of premature senescence. Cancer Cell 2008; 14: 79-89.

81. Nowak K, Kerl K, Fehr D, Kramps C, Gessner C, Killmer K et al. BMl1 is a target gene of E2F-1 and is strongly expressed in primary neuroblastomas. Nucleic Acids Res 2006; 34: 1745-1754

82. Cui H, Hu B, Li T, Ma J, Alam G, Gunning WT et al. Bmi-1 is essential for the tumorigenicity of neuroblastoma cells. Am J Pathol 2007; 170: 1370-1378.

83. Sparmann A, van Lohuizen M. Polycomb silencers control cell fate, development and cancer. Nat Rev Cancer 2006; 6: 846-856.

84. Jacobs JJ, Kieboom K, Marino S, DePinho RA, van Lohuizen M. The oncogene and Polycomb-group gene bmi-1 regulates cell proliferation and senescence through the ink4a locus. Nature 1999; 397: 164-168.

85. Lessard J, Sauvageau G. Bmi-1 determines the proliferative capacity of normal and leukaemic stem cells. Nature 2003; 423: 255-260.

86. Park IK, Qian D, Kiel M, Becker MW, Pihalja M, Weissman IL et al. Bmi-1 is required for maintenance of adult self-renewing haematopoietic stem cells. Nature 2003; 423 302-305.

87. Molofsky AV, Pardal R, Iwashita T, Park IK, Clarke MF, Morrison SJ. Bmi-1 dependence distinguishes neural stem cell self-renewal from progenitor proliferation. Nature 2003 425: 962-967.

88. Molofsky AV, He S, Bydon M, Morrison SJ, Pardal R. Bmi-1 promotes neural stem cell self-renewal and neural development but not mouse growth and survival by repressing the $\mathrm{p} 16^{\operatorname{lnk} 4 a}$ and $\mathrm{p} 19^{\text {Arf }}$ senescence pathways. Genes Dev 2005; 19: 1432-1437.

89. van Lohuizen M, Verbeek S, Scheijen B, Wientjens E, van der Gulden H, Berns A Identification of cooperating oncogenes in $\mathrm{E} \mu-m y c$ transgenic mice by provirus tagging. Cell 1991; 65: 737-752.

90. Haupt $Y$, Alexander WS, Barri G, Klinken SP, Adams JM. Novel zinc finger gene implicated as myc collaborator by retrovirally accelerated lymphomagenesis in $\mu$-myc transgenic mice. Cell 1991; 65: 753-763.
91. Haupt $\mathrm{Y}$, Bath ML, Harris AW, Adams JM. bmi-1 transgene induces lymphomas and collaborates with myc in tumorigenesis. Oncogene 1993; 8: 3161-3164.

92. Alkema MJ, Jacobs $H$, van Lohuizen $M$, Berns A. Pertubation of $B$ and $T$ cell development and predisposition to lymphomagenesis in $\mathrm{E}_{\mu} \mathrm{Bmi1}$ transgenic mice require the $\mathrm{Bmi} 1$ RING finger. Oncogene 1997; 15: 899-910.

93. Jacobs JJ, Scheijen B, Voncken JW, Kieboom K, Berns A, van Lohuizen M. Bmi-1 collaborates with c-Myc in tumorigenesis by inhibiting c-Myc-induced apoptosis via INK4a/ ARF. Genes Dev 1999; 13: 2678-2690.

94. Datta S, Hoenerhoff MJ, Bommi P, Sainger R, Guo WJ, Dimri M et al. Bmi-1 cooperates with $\mathrm{H}$-Ras to transform human mammary epithelial cells via dysregulation of multiple growth-regulatory pathways. Cancer Res 2007; 67: 10286-10295

95. Hernando E, Nahle Z, Juan G, Diaz-Rodriguez E, Alaminos M, Hemann M et al. Rb inactivation promotes genomic instability by uncoupling cell cycle progression from mitotic control. Nature 2004; 430: 797-802.

96. Strieder V, Lutz W. E2F proteins regulate MYCN expression in neuroblastomas. J Biol Chem 2003; 278: 2983-2989.

97. Cui H, Ma J, Ding J, Li T, Alam G, Ding HF. Bmi-1 regulates the differentiation and clonogenic self-renewal of I-type neuroblastoma cells in a concentration-dependent manner. J Biol Chem 2006; 281: 34696-34704

98. White PS, Thompson PM, Gotoh T, Okawa ER, Igarashi J, Kok M et al. Definition and characterization of a region of $1 \mathrm{p} 36.3$ consistently deleted in neuroblastoma. Oncogene 2005; 24: 2684-2694.

99. Okawa ER, Gotoh T, Manne J, Igarashi J, Fujita T, Silverman KA et al. Expression and sequence analysis of candidates for the 1p36.31 tumor suppressor gene deleted in neuroblastomas. Oncogene 2008; 27: 803-810.

100. Fujita T, Igarashi J, Okawa ER, Gotoh T, Manne J, Kolla $V$ et al. CHD5, a tumor suppressor gene deleted from $1 \mathrm{p} 36.31$ in neuroblastomas. J Natl Cancer Inst 2008; 100: 940-949.

101. Thompson PM, Gotoh T, Kok M, White PS, Brodeur GM. CHD5, a new member of the chromodomain gene family, is preferentially expressed in the nervous system. Oncogene 2003; 22: 1002-1011.

102. Bagchi A, Papazoglu C, Wu Y, Capurso D, Brodt M, Francis D et al. CHD5 is a tumor suppressor at human 1p36. Cell 2007; 128: 459-475.

103. Bown N, Cotterill S, Lastowska M, O'Neill S, Pearson AD, Plantaz D et al. Gain of chromosome arm $17 q$ and adverse outcome in patients with neuroblastoma. $N$ Engl $J$ Med 1999; 340: 1954-1961.

104. Vandesompele J, Baudis M, De Preter K, Van Roy N, Ambros P, Bown N et al. Unequivocal delineation of clinicogenetic subgroups and development of a new model for improved outcome prediction in neuroblastoma. J Clin Oncol 2005; 23: 2280-2299.

105. Saito-Ohara F, Imoto I, Inoue J, Hosoi H, Nakagawara A, Sugimoto T et al. PPM1D is a potential target for 17q gain in neuroblastoma. Cancer Res 2003; 63: 1876-1883.

106. Li J, Yang Y, Peng Y, Austin RJ, van Eyndhoven WG, Nguyen KC et al. Oncogenic properties of PPM1D located within a breast cancer amplification epicenter at 17q23. Nat Genet 2002; 31: 133-134.

107. Bulavin DV, Demidov ON, Saito S, Kauraniemi P, Phillips C, Amundson SA et al. Amplification of PPM1D in human tumors abrogates p53 tumor-suppressor activity. Nat Genet 2002; 31: 210-215.

108. Rauta J, Alarmo EL, Kauraniemi $P$, Karhu R, Kuukasjarvi T, Kallioniemi A. The serinethreonine protein phosphatase $P P M 1 D$ is frequently activated through amplification in aggressive primary breast tumours. Breast Cancer Res Treat 2006; 95: 257-263.

109. Hirasawa A, Saito-Ohara F, Inoue J, Aoki D, Susumu N, Yokoyama T et al. Association of 17q21-q24 gain in ovarian clear cell adenocarcinomas with poor prognosis and identification of PPM1D and APPBP2 as likely amplification targets. Clin Cancer Res 2003; 9: 1995-2004.

110. Mendrzyk F, Radlwimmer B, Joos S, Kokocinski F, Benner A, Stange DE et al. Genomic and protein expression profiling identifies $\mathrm{CDK} 6$ as novel independent prognostic marker in medulloblastoma. J Clin Oncol 2005; 23: 8853-8862.

111. Castellino RC, De Bortoli M, Lu X, Moon SH, Nguyen TA, Shepard MA et al. Medulloblastomas overexpress the p53-inactivating oncogene WIP1/PPM1D. $J$ Neurooncol 2008; 86: 245-256.

112. Fiscella M, Zhang H, Fan S, Sakaguchi K, Shen S, Mercer WE et al. Wip1, a novel human protein phosphatase that is induced in response to ionizing radiation in a p53-dependent manner. Proc Natl Acad Sci USA 1997; 94: 6048-6053.

113. Takekawa M, Adachi M, Nakahata A, Nakayama I, Itoh F, Tsukuda $\mathrm{H}$ et al. p53-inducible Wip1 phosphatase mediates a negative feedback regulation of p38 MAPK-p53 signaling in response to UV radiation. EMBO J 2000; 19: 6517-6526.

114. Lu X, Nannenga B, Donehower LA. PPM1D dephosphorylates Chk1 and p53 and abrogates cell cycle checkpoints. Genes Dev 2005; 19: 1162-1174.

115. Fujimoto $\mathrm{H}$, Onishi N, Kato N, Takekawa M, Xu XZ, Kosugi A et al. Regulation of the antioncogenic Chk2 kinase by the oncogenic Wip1 phosphatase. Cell Death Differ 2006; 13: $1170-1180$

116. Yoda $\mathrm{A}, \mathrm{Xu} X \mathrm{X}$, Onishi N, Toyoshima $\mathrm{K}$, Fujimoto $\mathrm{H}$, Kato $\mathrm{N}$ et al. Intrinsic kinase activity and $\mathrm{SQ} / \mathrm{TQ}$ domain of Chk2 kinase as well as N-terminal domain of Wip1 phosphatase are required for regulation of Chk2 by Wip1. J Biol Chem 2006; 281: 24847-24862.

117. Oliva-Trastoy M, Berthonaud V, Chevalier A, Ducrot C, Marsolier-Kergoat MC, Mann C et al. The Wip1 phosphatase (PPM1D) antagonizes activation of the Chk2 tumour suppressor kinase. Oncogene 2007; 26: 1449-1458. 
118. Shreeram S, Demidov ON, Hee WK, Yamaguchi H, Onishi N, Kek C et al. Wip1 phosphatase modulates ATM-dependent signaling pathways. Mol Cell 2006; 23: 757-764.

119. Shreeram S, Hee WK, Demidov ON, Kek C, Yamaguchi H, Fornace Jr AJ et al. Regulation of ATM/p53-dependent suppression of myc-induced lymphomas by Wip1 phosphatase. J Exp Med 2006; 203: 2793-2799.

120. Yamaguchi H, Durell SR, Chatterjee DK, Anderson CW, Appella E. The Wip1 phosphatase PPM1D dephosphorylates SQ/TQ motifs in checkpoint substrates phosphorylated by PI3K-like kinases. Biochemistry 2007; 46: 12594-12603.

121. Lu X, Ma O, Nguyen TA, Jones SN, Oren M, Donehower LA. The Wip1 phosphatase acts as a gatekeeper in the p53-Mdm2 autoregulatory loop. Cancer Cell 2007; 12: 342-354.

122. Bulavin DV, Phillips C, Nannenga B, Timofeev O, Donehower LA, Anderson CW et al. Inactivation of the Wip1 phosphatase inhibits mammary tumorigenesis through p38 MAPK-mediated activation of the $16^{\text {Ink4a }}$-p $19^{\text {Arf }}$ pathway. Nat Genet 2004; 36: 343-350.

123. Nannenga B, Lu X, Dumble M, Van Maanen M, Nguyen TA, Sutton R et al. Augmented cancer resistance and DNA damage response phenotypes in PPM1D null mice. $\mathrm{Mol}$ Carcinog 2006; 45: 594-604.

124. Demidov ON, Kek C, Shreeram S, Timofeev O, Fornace AJ, Appella E et al. The role of the MKK6/p38 MAPK pathway in Wip1-dependent regulation of ErbB2-driven mammary gland tumorigenesis. Oncogene 2007; 26: 2502-2506.

125. Moll UM, LaQuaglia M, Benard J, Riou G. Wild-type p53 protein undergoes cytoplasmic sequestration in undifferentiated neuroblastomas but not in differentiated tumors. Proc Natl Acad Sci USA 1995; 92: 4407-4411.

126. Wolff A, Technau A, Ihling $C$, Technau-Ihling K, Erber R, Bosch FX et al. Evidence that wild-type p53 in neuroblastoma cells is in a conformation refractory to integration into the transcriptional complex. Oncogene 2001; 20: 1307-1317.

127. Moll UM, Ostermeyer AG, Haladay R, Winkfield B, Frazier M, Zambetti G. Cytoplasmic sequestration of wild-type p53 protein impairs the $\mathrm{G}_{1}$ checkpoint after DNA damage. Mol Cell Biol 1996; 16: 1126-1137.

128. Nikolaev AY, Li M, Puskas N, Qin J, Gu W. Parc: a cytoplasmic anchor for p53. Cell 2003; 112: $29-40$.

129. Smart P, Lane EB, Lane DP, Midgley C, Vojtesek B, Lain S. Effects on normal fibroblasts and neuroblastoma cells of the activation of the $\mathrm{p} 53$ response by the nuclear export inhibitor leptomycin B. Oncogene 1999; 18: 7378-7386.

130. Becker K, Marchenko ND, Maurice M, Moll UM. Hyperubiquitylation of wild-type p53 contributes to cytoplasmic sequestration in neuroblastoma. Cell Death Differ 2007; 14: 1350-1360.

131. Rodriguez-Lopez AM, Xenaki D, Eden TO, Hickman JA, Chresta CM. MDM2 mediated nuclear exclusion of p53 attenuates etoposide-induced apoptosis in neuroblastoma cells. Mol Pharmacol 2001; 59: 135-143.
132. Wang X, Zalcenstein A, Oren M. Nitric oxide promotes p53 nuclear retention and sensitizes neuroblastoma cells to apoptosis by ionizing radiation. Cell Death Differ 2003; 10: $468-476$.

133. Stommel JM, Marchenko ND, Jimenez GS, Moll UM, Hope TJ, Wahl GM. A leucine-rich nuclear export signal in the p53 tetramerization domain: regulation of subcellular localization and p53 activity by NES masking. EMBO J 1999; 18: 1660-1672.

134. Lu W, Pochampally R, Chen L, Traidej M, Wang Y, Chen J. Nuclear exclusion of p53 in a subset of tumors requires MDM2 function. Oncogene 2000; 19: 232-240.

135. Flaegstad T, Andresen PA, Johnsen Jl, Asomani SK, Jorgensen GE, Vignarajan S et al. A possible contributory role of BK virus infection in neuroblastoma development. Cancer Res 1999; 59: 1160-1163.

136. Jorgensen GE, Johnsen JI, Ponthan F, Kogner P, Flaegstad T, Traavik T. Human polyomavirus BK (BKV) and neuroblastoma: mechanisms of oncogenic action and possible strategy for novel treatment. Med Pediatr Oncol 2000; 35: 593-596.

137. Sengupta S, Vonesch JL, Waltzinger $\mathrm{C}$, Zheng H, Wasylyk B. Negative cross-talk between $\mathrm{p} 53$ and the glucocorticoid receptor and its role in neuroblastoma cells. EMBO J 2000; 19: 6051-6064.

138. Ohtsubo C, Shiokawa D, Kodama M, Gaiddon C, Nakagama H, Jochemsen AG et al. Cytoplasmic tethering is involved in synergistic inhibition of p53 by Mdmx and Mdm2. Cancer Sci 2009; 100: 1291-1299.

139. Zaika A, Marchenko N, Moll UM. Cytoplasmically 'sequestered' wild type p53 protein is resistant to Mdm2-mediated degradation. J Biol Chem 1999; 274 27474-27480.

140. Chen Z, Lin Y, Barbieri E, Burlingame S, Hicks J, Ludwig A et al. Mdm2 deficiency suppresses MYCN-driven neuroblastoma tumorigenesis in vivo. Neoplasia 2009; 11 753-762.

141. Zindy F, Eischen CM, Randle DH, Kamijo T, Cleveland JL, Sherr CJ et al. Myc signaling via the ARF tumor suppressor regulates p53-dependent apoptosis and immortalization. Genes Dev 1998; 12: 2424-2433.

142. Aslanian A, laquinta PJ, Verona R, Lees JA. Repression of the Arf tumor suppressor by E2F3 is required for normal cell cycle kinetics. Genes Dev 2004; 18: 1413-1422.

143. Komori H, Enomoto M, Nakamura M, Iwanaga R, Ohtani K. Distinct E2F-mediated transcriptional program regulates $p 14^{A R F}$ gene expression. EMBO J 2005; 24 3724-3736.

144. Barbieri E, Mehta $P$, Chen Z, Zhang L, Slack A, Berg S et al. MDM2 inhibition sensitizes neuroblastoma to chemotherapy-induced apoptotic cell death. Mol Cancer Ther 2006; 5 2358-2365.

145. Van Maerken T, Ferdinande L, Taildeman J, Lambertz I, Yigit N, Vercruysse L et al. Antitumor activity of the selective MDM2 antagonist nutlin-3 against chemoresistant neuroblastoma with wild-type p53. J Natl Cancer Inst 2009 (in press). 